\title{
Leukocyte count affects expression of reference genes in canine whole blood samples
}

Christine J Piek $^{1 *}$, Bas Brinkhof ${ }^{1}$, Jan Rothuizen ${ }^{1}$, Aldo Dekker², Louis C Penning ${ }^{1}$

\begin{abstract}
Background: The dog is frequently used as a model for hematologic human diseases. In this study the suitability of nine potential reference genes for quantitative RT-PCR studies in canine whole blood was investigated.

Findings: The expression of these genes was measured in whole blood samples of 263 individual dogs, representing 73 different breeds and a group of 40 mixed breed dogs, categorized into healthy dogs and dogs with internal and hematological diseases, and dogs that underwent a surgical procedure. GeNorm analysis revealed that a combination of 5 to 6 of the most stably expressed genes constituted a stable normalizing factor. Evaluation of the expression revealed different ranking of reference genes in Normfinder and GeNorm. The disease category and the white blood cell count significantly affected reference gene expression.

Conclusions: The discrepancy between the ranking of reference genes in this study by Normfinder and Genorm can be explained by differences between the experimental groups such as "disease category" and "WBC count". This stresses the importance of assessing the expression stability of potential reference genes for gene experiments in canine whole blood anew for each specific experimental condition.
\end{abstract}

\section{Findings \\ Context}

The dog is frequently used as an experimental model for hematologic human diseases [1]. The use of dogs can be explained by the fact that the dog offers a variety of spontaneous and experimental models of hematologic diseases. Recent examples are the use of canine hemophilia A [2] and B models [3,4], and the Canine Leukocyte Adhesion Deficiency model (CLAD) $[5,6]$ in gene therapy experiments [2-8], and pharmacological experiments in leukopenic dogs [7] and in dogs with CLAD [8]. The larger size of dogs compared to small rodent models allows similar surgical procedures in humans as in dogs, and permits in most cases adequate acquisition of diagnostic samples. The dog has been a longstanding model for bone marrow and more recently for stem cell transplantations $[9,10]$. Anticoagulant therapy has been tested extensively in canine cardiac surgery models $[11,12]$. Also the pathogenesis and therapy of acquired disorders of hemostasis such

\footnotetext{
* Correspondence: C.J.Piek@uu.nl

'Department of Clinical Sciences of Companion Animals, Utrecht, Utrecht University, PO Box 80154, 3508 TD Utrecht, The Netherlands

Full list of author information is available at the end of the article
}

as disseminated intravascular coagulation [13], thrombosis $[14,15]$, and hemolytic uremic syndrome [16] have been investigated in canine models.

A disadvantage of the canine model compared to human or small rodent models is the limited availability of antibodies against canine intra- and extracellular proteins such as CD markers. At least $350 \mathrm{CD}$ markers are defined in humans $[17,18]$, while in the first and to date only workshop on canine leukocyte antigens only 127 antibodies were investigated [19]. A more recent study tested cross species reactivity with commercially available anti human CD molecules against canine leukocytes, erythrocytes and platelets and identified only a limited number of 51 cross reacting mAbs [20]. In contrast to the limited knowledge of canine CD markers, the canine genome has been sequenced in total [21]. Therefore most molecular tools can be readily applied in dog research. Real-time quantitative reverse transcriptase PCR (Q-PCR) offers an accurate and sensitive alternative to quantification of gene expression [22] and for that reason is well suited to study biological processes and has also many practical clinical applications. Q-PCR has already been shown to be a valuable adjunct in
Ciomed Central

(c) 2011 Piek et al; licensee BioMed Central Ltd. This is an open access article distributed under the terms of the Creative Commons Attribution License (http://creativecommons.org/licenses/by/2.0), which permits unrestricted use, distribution, and reproduction in any medium, provided the original work is properly cited. 
immunophenotyping and the quantification of residual disease in leukemia [23-26].

Multiple variables need to be controlled when performing a Q-PCR, such as the quality of RNA after isolation, the input amount and quality of mRNA and cDNA reaction efficacy, efficiency of the enzymatic reactions, and cell to cell variability in translational activity. One of the solutions to control for the internal variation that affect the outcome of the Q-PCR reaction is the use of reference genes as an internal standard [22,27]. Reference genes are selected based on the supposition that their expression is stable in all cells regardless of the tissue or individual [28]. It has been proven, however, that many genes essential for basic cellular mechanisms and hitherto thought to have a stable expression throughout the organism actually did not comply with this assumption [29-35]. Therefore, it is essential that the assumption of stable expression of potential reference genes is verified for each experimental set up [28,36-38].

In this study we investigated the suitability of nine frequently used reference genes in Q-PCR for the use as reference genes in a quantitative real-time PCR in canine whole blood and the influence of dog breed, sex, disease category and disease duration on the $\mathrm{Cq}$ of these genes was assessed.

\section{Methods}

\section{Blood sample collection}

Between September 2007 and October 2008 canine blood samples $(n=263)$ were taken from dogs submitted to the intensive care unit of the small animal hospital of the Veterinary Faculty of the Utrecht University (The Netherlands) from healthy control dogs $(n=6$; group A) and dogs categorized into three disease groups. Group B $(n=85)$ had surgery within the preceding 24 hours, group $C(n=107)$ were dogs with miscellaneous internal diseases, and group D $(n=65)$ had hematologic disease (disseminated intravascular coagulation $(\mathrm{n}=27)$, systemic inflammatory disease $(\mathrm{n}=24)$, and immunemediated hemolysis $(\mathrm{n}=14)$.

The 263 dogs represented 73 different breeds and a group of mixed breed dogs $(n=40)$. Breeds that were represented by at least 5 dogs were the Labrador retriever $(n=30)$, Golden retriever $(n=18)$, Jack Russell terrier $(n=10)$, (Bordeaux $\operatorname{dog}(n=9)$, Dachshund $n=9)$, Boxer $(n=7)$, German shepherd and German pointer $(n=6)$, and the Bernese mountain dog, Beagle, English Cocker spaniel, and the Bearded collie were all represented by 5 dogs. There were 42 female dogs, 91 castrated female dogs, 78 males, and 47 castrated male dogs. Of 3 dogs the sex was not noted in the file. The mean age of the dogs was 6.5 years (range 12 weeks to 14 years, SD 3.5 years).
Two milliliters of EDTA-anticoagulated blood were collected from each dog on the day of admittance and during the period the dog was hospitalized consecutive samples were taken at least 24 hours apart.

From 99 of the dogs, a second sample was available ( 37 of group B, 30 of group C, 32 of group D), and in, respectively, 34 dogs a third (10 of group B, 6 of group $C, 18$ of group D), and in 13 dogs a fourth sample (4 of group B, 3 of group C, 6 of group D) was available.

All procedures were approved by and performed according to the ethical committee as required under Dutch legislation.

\section{RNA isolation and CDNA synthesis}

In view of the large sample number but small samples size, the RT-reaction was performed only once. The MIQE guidelines, however, suggest to perform it twice $[39,40]$. From each dog duplo samples were prepared by mixing $0.5 \mathrm{ml}$ EDTA-anticoagulated blood with $1.3 \mathrm{ml}$ RNAlater (Ambion, Applied Biosystems, Foster City, California, USA). Samples were stored at $-20^{\circ} \mathrm{C}$. Total RNA was extracted from the samples using the RiboPure ${ }^{\mathrm{TM}}$-Blood kit reagent (Ambion, Applied Biosystems, Foster City, USA) according to the manufacturer's instructions including a DNAse treatment to destroy contaminating genomic DNA and minimize the effect of pseudogenes. The RNA concentration was determined spectrophotometrically by the NANOdrop 1000 Isogen Life Science, IJsselstein, The Netherlands). Bio-Rad iScript, containing both oligodT and random hexamer primers, was used to synthesize cDNA from $1 \mu \mathrm{g}$ of total RNA according to the manufacturer's instructions (iSCRIPT, Bio-Rad, Veenendaal, The Netherlands).

\section{Primer design and testing}

The selection and testing of candidate reference genes was based on gene targets that have already been used in human and veterinary research, and have been previously reported $[41,42]$. Nine genes representing various biological processes (GAPDH, SRPR, HPRT, B2M, GUSB, HNRNPH, RPL8, RPS5, RPS19) were selected as candidate reference genes. Their full names, GenBank accession numbers, and location in the canine chromosome are given in Table 1 . The primers that were used, location of these primers within the gene, and the length of the resulting amplicon are given in Table 2. Primers were developed based upon known canine sequences (Ensembl, http://www.ensembl.org and GenBank, http:// www.ncbi.nih.gov/genbank/index.html). The primers were designed with Oligo Explorer 1.1 (http://www.genelink.com/tools/gl-downloads.asp). The specificity and uniqueness of each primer were verified with the Basic Local Alignment Search tool expecting return of Genbank accession numbers of candidate reference genes 
Table 1 Abbreviations, GenBank Accession numbers, names, and chromosomal location of canine candidate reference genes evaluated

\begin{tabular}{llll}
\hline Gene & GenBank Accession No. & Name & Chromosomal location in Canis familiaris \\
\hline RPS19 & XM_533657 & Ribosomal protein S19 & Chromosome 1 \\
RPL8 & XM_532360 & Ribosomal protein L8 & Chromosome 13 \\
RPS5 & XM_533568 & Ribosomal protein S5 & Chromosome 1 \\
GUSB & NM_001003191 & Beta-Glucuronidase & Chromosome 6 \\
B2M & XM_535458 & Beta-2-microglobulin & Chromosome 30 \\
HNRNPH & XM_538576 & Heterogeneous nuclear ribonucleoprotein H & Chromosome 11 \\
HPRT & AY283372 & Hypoxanthine phosphoribosyltransferase 1 & Chromosome X \\
GAPDH & NM_001003142 & Glyceraldehyde-3-phosphate dehydrogenase & Chromosome X \\
SRPR & X03184 & Signal recognition particle receptor & Chromosome 5 \\
\hline
\end{tabular}

only (http://www.genelink.com/tools/gl-downloads.asp). All primer pairs, except for GAPDH, were intron spanning. The PCR reaction was optimized for the primers. Optimal Tm values ranged from $55^{\circ} \mathrm{C}$ for $\mathrm{RPL} 8$ to $62.5^{\circ} \mathrm{C}$ for RPS5 (Table 2). Amplification efficiency calculations from all standard curves were between 93.9 and $106.7 \%$. All no template controls were negative.

\section{Quantitative PCR}

Q-PCR was done with the DNA-binding SYBR green using the BioRad iCycler MyiQ Real-Time PCR Detection System (BioRad, Hertfordshire, United Kingdom) according to the manufacturer's instructions. Primers (Eurogentec, Maastricht, The Netherlands) had a final concentration of $400 \mathrm{nM}$ each. One microliter of cDNA was used per Q-PCR reaction. Optimal $T_{\mathrm{m}}$ was determined previously $[41,42]$. Reactions with a $T_{\mathrm{m}}$ less than $58^{\circ} \mathrm{C}$ started with $5 \mathrm{~min}$ at $95^{\circ} \mathrm{C}$, followed by 40 cycles of $20 \mathrm{~s}$ at $95^{\circ} \mathrm{C}, 30 \mathrm{~s}$ at $T_{\mathrm{m}}$, and $30 \mathrm{~s}$ at $72^{\circ} \mathrm{C}$. This reaction was continued by a melting curve, stepwise increasing temperature each $15 \mathrm{~s}$ by $0.5^{\circ} \mathrm{C}$, ranging from 60 to $95^{\circ} \mathrm{C}$. In case the $T_{\mathrm{m}}$ was $58^{\circ} \mathrm{C}$ or higher, the elongation step at $72^{\circ} \mathrm{C}$ was omitted and $T_{\mathrm{m}}$ remained $30 \mathrm{~s}$. Analysis of Q-PCR results were performed with $\mathrm{iQ}^{\mathrm{TM}} 5$ software (Biorad, Veenendaal, The Netherlands) based on the mean $\mathrm{Cq}$ obtained from the duplo of each $\mathrm{Q}-\mathrm{PCR}$ reaction.

\section{Analysis gene expression}

Firstly, the influence of experimental condition such as disease category and duration, sex, leukocyte count on potential reference gene expression were determined. For each potential reference gene a comparison of the mean $\mathrm{Cq}$ values obtained at the first sampling for the disease groups A, B, C, and D, and sex was performed using the ANOVA. To determine if the differences in Cq's for the nine potential reference genes were due to changes in expression levels over time an ANOVA was used. Using a forward selection process, two explanatory variables, "dog" and "sample number", were introduced as factors in the ANOVA. The result variable was the observed $\mathrm{Cq}$ value. The resulting models were compared using the likelihood ratio test.

The mean $\mathrm{Cq}$ values for dogs with a leukocyte count within the reference range $\left(4.5-14.6 * 10^{9} / \mathrm{l}\right)$ were compared to mean Cq's of dogs with a leukocyte count above $30 * 10^{9} / 1$, which can be considered a clinically relevant leukocytosis. If a significant difference was

Table 2 Primer sequences, exon locations, amplicon size, and optimal melting temperature of canine candidate reference genes

\begin{tabular}{|c|c|c|c|c|c|c|}
\hline Gene & Forward $5^{\prime} \rightarrow 3^{\prime *}$ & Exon(s) & Reverse $5^{\prime} \rightarrow 3^{\prime}$ & Exon(s) & Product length (bp) & $\mathrm{T}_{\mathrm{m}}\left({ }^{\circ} \mathrm{C}\right)$ \\
\hline RPS19 & CCTTCCTCAAAAA/GTCTGGG & $2 / 3$ & GTTCTCATCGTAGGGAGCAAG & 3 & 95 & 61.0 \\
\hline RPL8 & CCATGAAT/CCTGTGGAGC & $4 / 5$ & GTAGAGGGTITGCCGATG & 5 & 64 & 55.0 \\
\hline RPS5 & TCACTGGTGAG/AACCCCCT & $2 / 3$ & CCTGATTCACACGGCGTAG & 3 & 141 & 62.5 \\
\hline GUSB & AGACGCTTCCAA/GTACCCC & $3 / 4$ & AGGTGTGGTGTAGAGGAGCAC & 4 & 103 & 62.0 \\
\hline B2M & TCCTCATCСTCCTCGCT & 1 & TTCTCTGCTGGGTGTCG & 2 & $85^{\dagger}$ & 61.2 \\
\hline HNRNPH & CTCACTATGATCCACCACG & 5 & TAGCCTCCATAAC/CTCCAC & $5 / 6$ & 151 & 61.2 \\
\hline HPRT & AG/CTTGCTGGTGAAAAGGAC & $5 / 6$ & TTATAGTCAAGGGCATATCC & 7 & $114^{\ddagger}$ & 56.0 \\
\hline GAPDH & TGTCCCCACCCCCAATGTATC & 2 & СTCCGATGCCTGCTTCACTACCT & 2 & 100 & 58.0 \\
\hline SRPR & GCTTCAGGATCTGGACTGC & $5 / 6$ & GTTCCCTTGGTAGCACTGG & 6 & 81 & 61.2 \\
\hline
\end{tabular}

* If a primer is located on two exons, the junctions are shown with a dividing forward slash (/).

${ }^{\dagger}$ Genomic product size would be approximately $3.6 \mathrm{~kb}$.

* Genomic product size would be approximately $300 \mathrm{bp}$. 
observed, a pair wise comparison was made using the T-test with Holmes correction for multiple comparisons. Secondly, a linear mixed effects model was used to assess the significance as well as the magnitude of the effect of leukocyte count on Cq per dog, with the mean $\mathrm{Cq}$ as response variable, the natural logarithm of the "leukocyte count" as explanatory variable, and the "dog" as random effect. Similarly, a linear mixed effects model was used to determine if the leukocytes count changed over time per dog. An ANOVA was used to compare the leukocyte counts in the disease groups A, B, C and D. A linear model was used to examine the relationship of the Cq with the variables "disease category" and the natural logarithm of the "leukocyte count".

All statistical analyses were performed in R (http:// www.r-project.org). P below 0.05 was considered significant in all analyses.

To determine the ranking of best performing reference genes in whole blood the stability of expression of the candidate reference genes was calculated using the GeNorm [27] and Normfinder [43] algorithm software. The gene expression stability calculations in this study were performed on the first sample that was taken when the dog entered the study.

In Genorm the expression ratio for each pair of candidate reference genes is calculated for the data array of all samples and $\log _{2}$-transformed. " $M$ " is the arithmetic mean of the pair wise variation measured as the standard deviation of thus obtained values. A low "M" indicates little variation in expression of the two genes. Then the optimal number of control genes for normalisation is determined. Firstly, the normalisation factor is calculated based on the two reference genes with the lowest "M"-values. Secondly, the contribution of an additional candidate reference gene to the variance of the normalisation factor ratios is calculated by the stepwise introduction of the reference genes following the earlier established ranking order of their " $M$ "-values.

Shortly, Normfinder makes use of a mathematical model to describe the expression values measured by RT-PCR, separate analysis of the sample subgroups, and estimation of both the intra- and the intergroup expression variation, and finally calculates a candidate gene "Stability Value."

\section{Results}

\section{Expression of candidate reference genes}

The range and median $\mathrm{Cq}$ values of the first sample that was taken in the dogs in the disease groups A, B, C and $\mathrm{D}$ (described above) are depicted in Figure 1. There was a significant difference between the mean Cq's measured in groups B and C for RPL8, RPS19, B2M and HNRNPH, the differences being $0.35,0.39,0.44$, and $0.35 \mathrm{Cq}$, respectively. The difference between groups B

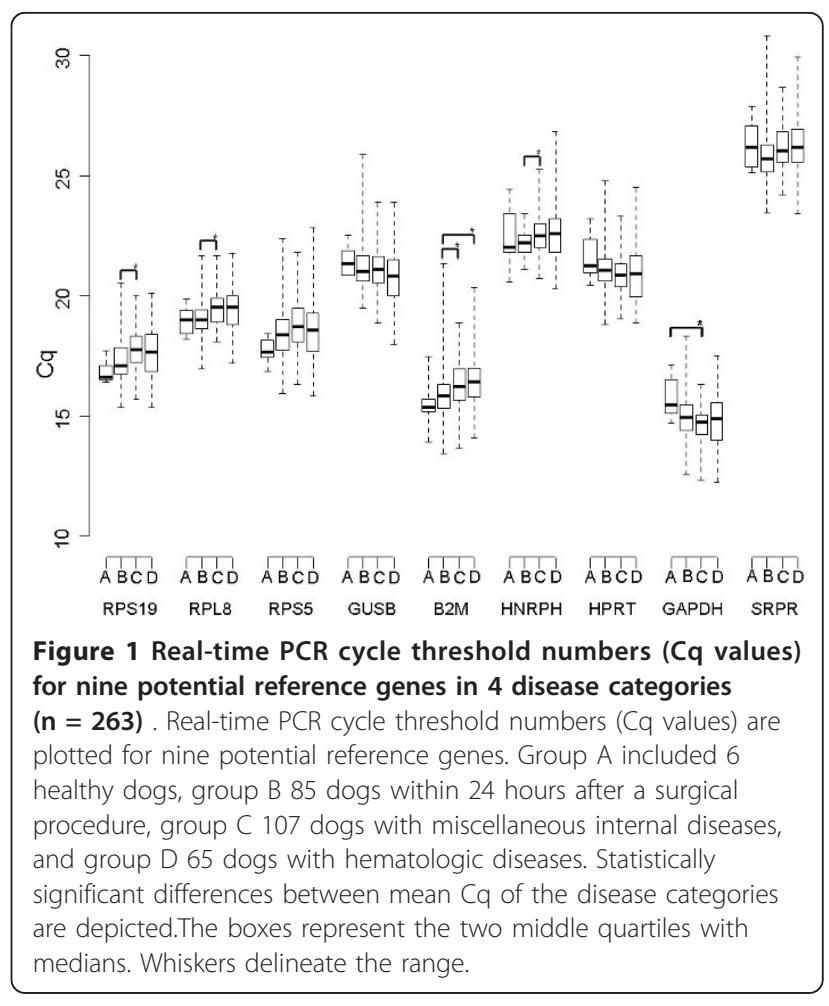

and D for B2M was $0.51 \mathrm{Cq}$, and between $\mathrm{A}$ and $\mathrm{C}$ for GAPDH it was 1.1 Cq (Figure 1). "Sample number" did not significantly determine the Cq, except for SRPR ( $\mathrm{p}=0.013$ ), nor did "sex" and "breed".

Next the leukocyte count was examined. The leukocyte counts of disease group A was within the reference range (median 8.6, range $6.6-12.5^{*} 10^{9} / \mathrm{l}$ ). The leukocyte counts of disease groups B (median 15.9, range 3.8 $107.8 * 10^{9} / \mathrm{l}$ ) and $C$ (median 16.8, range $2.1-44.6^{*} 10^{9} / \mathrm{l}$ ) were statistically significant from group D (median 22.6, range $\left.4.8-175.9 * 10^{9} / 1\right)\left(P=1.9 * 10^{-7}\right.$ and $7.8^{*} 10^{-6}$ respectively). The linear mixed effects model revealed that "leukocyte count" did not significantly change between sequential samples taken during the course of the disease.

The linear mixed effects model that included only "leukocyte count" as explanatory variable for the Cq was not significant for SRPR, HNRNPH, and GUSB. The other 6 potential reference genes (B2M, RPL8, RPS19, RPS5, GAPDH, and HPRT) had significant changes in $\mathrm{Cq}$, ranging from -0.87 to 1.28 for an a ten fold increase in leukocyte count. A significant difference between the Cq's of dogs with a leukocyte count within the reference range and dogs with a leukocyte count above $30 * 10^{9} / 1$ was found for RPS19, RPL8, RPS5, B2M, and HPRT. Additionally, in this analysis, GAPDH, was identified as the fourth of the nine reference genes that was not significantly influenced by leukocyte count (Table 3 ). 
Table 3 Relation of $\mathrm{Cq}$ and white blood cell count

\begin{tabular}{|c|c|c|c|c|c|c|c|c|}
\hline \multirow[t]{2}{*}{ Gene } & \multirow[t]{2}{*}{ Cq change for 10 fold increase in WBC count } & \multirow[t]{2}{*}{$\mathbf{p}$} & \multicolumn{2}{|c|}{ WBC within reference range } & \multicolumn{2}{|c|}{ WBC $>30 * 10^{9} / I$} & \multirow[t]{2}{*}{ Difference } & \multirow[t]{2}{*}{ p } \\
\hline & & & Mean $\mathrm{Cq}$ & SD & Mean $\mathrm{Cq}$ & SD & & \\
\hline RPS19 & 0.92 & 0 & 17.35 & 0.82 & 17.90 & 1.31 & 0.56 & 0.002 \\
\hline RPL8 & 0.52 & 0.006 & 19.20 & 0.67 & 19.52 & 1.14 & 0.32 & 0.026 \\
\hline RPS5 & 1.06 & 0 & 18.30 & 0.86 & 19.01 & 1.61 & 0.71 & 0.0009 \\
\hline GUSB & -0.07 & 0.75 & 21.09 & 0.97 & 21.08 & 1.47 & -0.01 & 0.93 \\
\hline B2M & 1.28 & 0 & 15.85 & 0.86 & 16.58 & 1.74 & 0.73 & 0.0006 \\
\hline HNRNPH & -0.09 & 0.68 & 22.40 & 0.86 & 22.20 & 1.02 & -0.20 & 0.19 \\
\hline HPRT & -0.87 & 0 & 21.14 & 0.93 & 20.71 & 1.03 & -0.43 & 0.01 \\
\hline GAPDH & -0.51 & 0.023 & 14.87 & 0.97 & 14.80 & 0.96 & -0.07 & 0.38 \\
\hline SRPR & 0.10 & 0.70 & 18.30 & 1.09 & 19.01 & 1.51 & 0.03 & 0.91 \\
\hline
\end{tabular}

- WBC $=$ White Blood Cell Count.

Change in Cq is given for a ten fold increase in WBC count, mean Cq and SD for dogs with WBC count in the reference range and for dogs with a leukocytosis with a WBC $>30^{*} 10^{9} /$.

The linear model that included both "leukocyte count" and the "disease category" as explanatory variables for the Cq was statistically significant for both RPS5 and B2M. "Disease category" was the statistically significant factor determining $\mathrm{Cq}$ in the case of SRPR, HNRNPH, GUSB and GAPDH and "leukocyte count" in the case of RPS19, RPL8, and HPRT.

In order to identify the genes that had the least variable expression, expression stability was evaluated using GeNorm and Normfinder software analysis. The pair wise variation between the normalisation factors calculated by GeNorm steadily decreased after inclusion of the fourth additional reference gene and falls below the cut-off of 0.15 that is suggested by the GeNorm programme after adding the fifth gene [27] (Figure 2). The ranking of the potential reference genes by GeNorm and Normfinder is given in Table 4.

\section{Discussion}

Studying gene expression by the sensitive, specific, and accurate technique of quantitative RT-PCR has become increasingly important in biomedical research. The goal of this study was to select reference genes that can be used as a normaliser when studying gene transcription in canine blood cells. Nine genes that are either conventionally used as reference genes or were shown to have a stable expression in hematopoietic cells or whole blood were chosen as potential candidate reference genes in this study $[36,41,42,44,45]$ (Table 1). Even genes that regulate basic cellular tasks have been shown to be regulated $[29-35,46]$. To exclude that the expression of the potential reference genes was influenced by the experimental conditions in our study we investigated the effect of several parameters such as disease category, disease duration, and leukocyte count. Additionally, two software algorithms, respectively, Normfinder [43] and
GeNorm [27], were used to calculate gene expression stability and help select the combination of reference genes that provides the most stable normalizer for a specific experimental situation.

Whole blood RNA originating from all cells present in the peripheral blood, as opposed to RNA derived from a cell sorting procedure, was used for the reverse transcriptase reaction in this study. To correct for the leukocyte count reaction was performed on a fixed amount of starting RNA. The influence of a disproportionate increase of a subset of the leukocytes on reference gene expression is not countered by this. This disadvantage has to be weighed against the advantage of being able to investigate simultaneously the expression of multiple

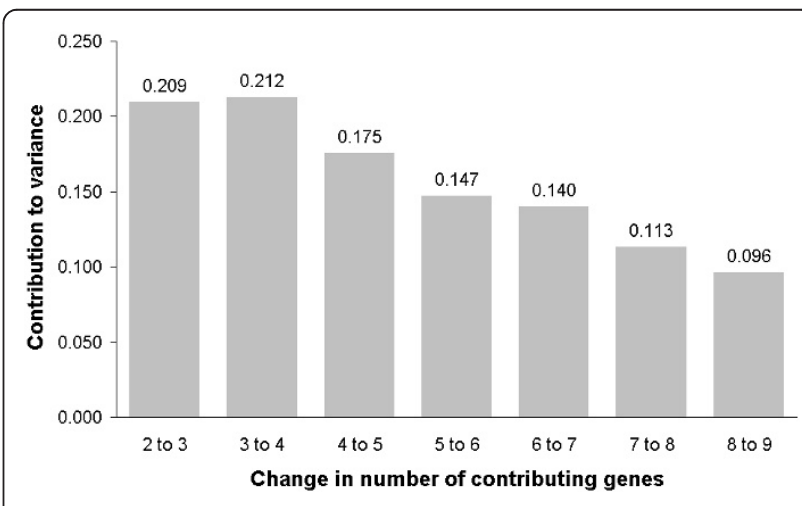

Figure 2 Pairwise variations between 2 sequential normalization factors including an increasing number of potential reference genes. To determine the optimal number of reference genes, first the geometric mean of the expression of the previously ranked genes was calculated and then pair wise variations between sequential normalisation factors were calculated. Using the cut-off recommended by GeNorm of 0.15 the optimal number of reference genes for the data set in this study would be at least 5 . 
Table 4 Ranking of potential reference genes according to their expression stability by GeNorm and Normfinder

\begin{tabular}{lclllc}
\hline GeNorm & $\begin{array}{c}\text { Stability measure* } \\
\text { M }\end{array}$ & $\begin{array}{l}\text { Normfinder } \\
\text { Disease category** }\end{array}$ & Stability Value* & $\begin{array}{l}\text { Normfinder } \\
\text { WBC quartiles*** }\end{array}$ & Stability Value* \\
\hline RPL8 and RPS19 & 0.55 & RPL8 & 0.16 & RPL8 & 0.09 \\
& & HNRNPH & 0.17 & HNRNPH & 0.14 \\
RPS5 & 0.64 & SRPR & 0.19 & GUSB & 0.14 \\
GUSB & 0.78 & GUSB & 0.26 & SRPR & 0.16 \\
B2M & 0.87 & HPRT & 0.26 & GAPDH & 0.17 \\
HNRNPH & 0.93 & RSP19 & 0.26 & RSP19 & 0.17 \\
HPRT & 0.99 & B2M & 0.28 & RPS5 & 0.21 \\
GAPDH & RPS5 & 0.32 & HPRT & 0.21 \\
SRPR & 1.01 & GAPDH & 0.35 & B2M & 0.21 \\
\hline
\end{tabular}

*Genes are ranked according to decreasing expression stability.

genes originating from distinct cell types. And, additionally, against the fact that cell sorting procedures have been shown to affect gene expression. Five to nine fold up regulation of cytokine expressions were seen after density gradient separation of leukocytes [47].

Several conditions that might effect gene expression were examined in this study. Figure 1 reveals significant increases in Cq between the disease groups for RPS19, RPL8, B2M, HNRNPH, and GAPDH, The maximum increase is seen in case of B2M between groups B and $\mathrm{D}(0.51 \mathrm{Cq})$. These differences between the disease groups can be contributed mainly to the disease condition as opposed to disease duration since the Cq was not significantly different between the sequential samples taken during the disease period in a subset of the dogs. The leukocyte count gradually increases comparing the disease groups, revealing a significant difference between group B (median leukocyte count $15.9 * 10^{9} / 1$ ) versus $C$ (median leukocyte count $16.8^{*} 10^{9} / 1$ ) and $\mathrm{D}$ (median leukocyte count $22.6 * 10^{9} / \mathrm{l}$ ), respectively. The changes in $\mathrm{Cq}$ associated with leukocyte count had a similar direction as the Cq changes in the disease categories (Figure 1). This suggested that "leukocyte count" might a major factor explaining the directional change in Cq. The linear model examining the influence of "disease category" and "leukocyte count" revealed that this was the case for RPS19 and RPL8. RPS5 and B2M were best explained by the linear model containing both parameters, however. The reference genes that were not significantly influenced by the WBC count were GUSB, HNRNPH and SRPR (Table 3).

B2M has shown a highly variable expression in several tissues other than whole blood $[41,42,44,48]$ but had a stable expression in one study where human leukocytes from 13 healthy donors were examined [27]. B2M also had stable expression in a large study where 526 human whole blood samples representing healthy individuals and 6 disease groups [49]. The influence of leukocyte count on B2M expression was not examined in both these studies. B2M encodes for beta-2-microglobulin which is part of the canine MHC I molecule and abundantly expressed on hematopoietic cells. The decrease in B2M expression associated with increases in leukocyte count in this study might reflect both a decrease in induced expression, or a shift in leukocyte subsets displaying different $\mathrm{MHC}$ class I receptor densities.

The selection of one, or a set of, potential reference genes for a future experiment depends besides practical points such as available sample sizes and costs mainly on stability of expression in the experimental samples. In this study we evaluated the expression stability with Normfinder and GeNorm. Both software algorithms are frequently used and freely available but have a different working rationale. Normfinder selects out of a set of potential reference genes one single, or the pair of, best performing reference genes that show the least variation between and within experimental groups. The focus on the detection of directional changes in reference gene expression due to differences between the experimental groups is the major difference with GeNorm that focuses on pair wise comparisons of reference gene expression in the experimental samples and is therefore less apt to identify coregulated genes [50]. Since WBC count and disease category had a statistically significant effect on potential reference gene expression, it is not surprising that the ranking provided by Normfinder and GeNorm differed. Among the genes ranked highest by Normfinder were the genes that were not significantly influenced by the WBC count (GUSB, HNRNPH and SRPR, Table 3).

Contrastingly, GeNorm ranked RPS8, RPS19, and RPS5 highest. Similarly, RPL8 had the best Stability Value in Normfinder, but both RSP19 and RSP5 were ranked at the low end of the list (Table 4). An explanation might be that these three genes are all coding for ribosomal proteins which are likely to be coregulated. Despite the fact that they have less variation in expression as pointed out by GeNorm, the directional 
difference in expression of these coregulated reference genes, will potentially decrease the sensitivity of detecting changes in expression of the genes of interest in an experiment [51].

The discrepancy between the ranking of reference genes in this study by Normfinder and Genorm can be explained by differences between the experimental groups such as "disease category" and "WBC count". These results reveal that experimental conditions can result in unforeseen group wise up regulation or down regulation of reference genes that otherwise may have a stable expression when the whole dataset is considered. Minor group specific directional changes in reference gene expression might obscure changes in candidate gene expression between groups. The results of this study emphasize that it is prudent to assess each new data set specifically for changes in reference gene expression due to the experimental conditions even when reference genes are chosen that were previously shown to have a stable expression.

\section{List of abbreviations}

B2M: beta-2-Microglobulin; GAPDH: Glyceraldehyde-3-phosphate dehydrogenase; GUSB: beta-Glucuronidase; HNRNPH: Heterogeneous nuclear ribonucleoprotein H; HPRT: Hypoxanthine phosphoribosyltransferase; RPL8: Ribosomal protein L8; RPS5: Ribosomal protein S5; RPS19: Ribosomal protein S19; SRPR: Signal recognition particle receptor.

\section{Author details}

${ }^{1}$ Department of Clinical Sciences of Companion Animals, Utrecht, Utrecht University, PO Box 80154, 3508 TD Utrecht, The Netherlands. ${ }^{2}$ Central Institute for Animal Disease Control, P.O. Box 2004, 8203 AA Lelystad, The Netherlands.

\section{Authors' contributions}

CJP participated in the experimental design, collected blood samples and drafted the manuscript. BB carried out the molecular analysis. JR was involved in the experimental design and sample collection. AD carried out the statistical analysis. LCP participated in the experimental design and coordination and drafted the manuscript.

All authors read and approved the final manuscript.

\section{Competing interests}

The authors declare that they have no competing interests.

Received: 18 August 2010 Accepted: 9 February 2011

Published: 9 February 2011

\section{References}

1. Starkey MP, Scase TJ, Mellersh CS, Murphy S: Dogs really are man's best friend-canine genomics has applications in veterinary and human medicine! Brief Funct Genomic Proteomic 2005, 4:112-128.

2. McCormack WM Jr, Seiler MP, Bertin TK, Ubhayakar K, Palmer DJ, Ng P, Nichols TC, Lee B: Helper-dependent adenoviral gene therapy mediates long-term correction of the clotting defect in the canine hemophilia A model. J Thromb Haemost 2006, 4:1218-1225.

3. Niemeyer GP, Herzog RW, Mount J, Arruda VR, Tillson DM, Hathcock J, van Ginkel FW, High KA, Lothrop CD Jr: Long term correction of inhibitor prone hemophilia $B$ dogs treated with liver-directed AAV2 mediated factor IX gene therapy. Blood 2009, 113:797-806.

4. Arruda VR, Stedman HH, Nichols TC, Haskins ME, Nicholson M, Herzog RW, Couto LB, High KA: Regional intravascular delivery of AAV-2-F.IX to skeletal muscle achieves long-term correction of hemophilia B in a large animal model. Blood 2005, 105:3458-3464.

5. Bauer TR Jr, Allen JM, Hai M, Tuschong LM, Khan IF, Olson EM, Adler RL, Burkholder TH, Gu YC, Russell DW, Hickstein DD: Successful treatment of canine leukocyte adhesion deficiency by foamy virus vectors. Nat Med 2008, 14:93-97.

6. Bauer TR Jr, Gu YC, Creevy KE, Tuschong LM, Embree L, Holland SM, Sokolic RA, Hickstein DD: Leukocyte adhesion deficiency in children and Irish setter dogs. Pediatr Res 2004, 55:363-367.

7. Choi EW, Koo HC, Shin IS, Chae YJ, Lee JH, Han SM, Lee SJ, Bhang DH, Park YH, Lee CW, Youn HY: Preventive and therapeutic effects of gene therapy using silica nanoparticles-binding of GM-CSF gene on white blood cell production in dogs with leukopenia. Exp Hematol 2008, 36:1091-1097.

8. Creevy KE, Bauer TR Jr, Tuschong LM, Embree LJ, Colenda L, Cogan K, Starost MF, Haskins ME, Hickstein DD: Canine leukocyte adhesion deficiency colony for investigation of novel hematopoietic therapies. Vet Immunol Immunopathol 2003, 94:11-22.

9. Ladiges WC, Storb R, Thomas ED: Canine models of bone marrow transplantation. Lab Anim Sci 1990, 40:11-15.

10. Lange S, Altmann S, Brandt B, Adam C, Riebau F, Vogel H, Weirich V, Hilgendorf I, Storb R, Freund M, Junghanss C: Investigation of immunological approaches to enhance engraftment in a 1 Gy TBI canine hematopoietic stem cell transplantation model. Exp Hematol 2009, 37:143-150.

11. Wakefield TW, Lindblad B, Whitehouse WM Jr, Hantler CB, Stanley JC: Attenuation of hemodynamic and hematologic effects of heparinprotamine sulfate interaction after aortic reconstruction in a canine model. Surgery 1986, 100:45-51.

12. Terrell MR, Walenga JM, Koza MJ, Pifarre R: Efficacy of aprotinin with various anticoagulant agents in cardiopulmonary bypass. Ann Thorac Surg 1996, 62:506-511.

13. Wigton DH, Kociba GJ, Hoover EA: Infectious canine hepatitis: animal model for viral-induced disseminated intravascular coagulation. Blood 1976, 47:287-296.

14. Comer MB, Cackett KS, Gladwell S, Wood LM, Dawson KM: Thrombolytic activity of BB-10153, a thrombin-activatable plasminogen. J Thromb Haemost 2005, 3:146-153.

15. Hong TT, Huang J, Barrett TD, Lucchesi BR: Effects of cyclooxygenase inhibition on canine coronary artery blood flow and thrombosis. Am J Physiol Heart Circ Physiol 2008, 294:H145-155.

16. Raife T, Friedman KD, Fenwick B: Lepirudin prevents lethal effects of Shiga toxin in a canine model. Thromb Haemost 2004, 92:387-393.

17. Zola H, Swart B, Banham A, Barry S, Beare A, Bensussan A, Boumsell L, C DB, Buhring HJ, Clark G, et al: CD molecules 2006-human cell differentiation molecules. J Immunol Methods 2007, 319:1-5.

18. Zola H, Swart B: The human leucocyte differentiation antigens (HLDA) workshops: the evolving role of antibodies in research, diagnosis and therapy. Cell Res 2005, 15:691-694.

19. Cobbold S, Metcalfe S: Monoclonal antibodies that define canine homologues of human CD antigens: summary of the First International Canine Leukocyte Antigen Workshop (CLAW). Tissue Antigens 1994, 43:137-154.

20. Schuberth HJ, Kucinskiene G, Chu RM, Faldyna M: Reactivity of crossreacting monoclonal antibodies with canine leukocytes, platelets and erythrocytes. Vet Immunol Immunopathol 2007, 119:47-55.

21. Lindblad-Toh K, Wade CM, Mikkelsen TS, Karlsson EK, Jaffe DB, Kamal M, Clamp M, Chang JL, Kulbokas EJ, Zody MC, et al: Genome sequence, comparative analysis and haplotype structure of the domestic dog. Nature 2005, 438:803-819.

22. Wong ML, Medrano JF: Real-time PCR for mRNA quantitation. BioTechniques 2005, 39:75-85.

23. Bustin SA, Mueller R: Real-time reverse transcription PCR (qRT-PCR) and its potential use in clinical diagnosis. Clin Sci (Lond) 2005, 109:365-379.

24. Pallisgaard N, Clausen N, Schroder H, Hokland P: Rapid and sensitive minimal residual disease detection in acute leukemia by quantitative real-time RT-PCR exemplified by $\mathrm{t}(12 ; 21)$ TEL-AML1 fusion transcript. Genes Chromosomes Cancer 1999, 26:355-365.

25. Meijerink J, Mandigers C, van de Locht L, Tonnissen E, Goodsaid F, Raemaekers J: A novel method to compensate for different amplification 
efficiencies between patient DNA samples in quantitative real-time PCR. J Mol Diagn 2001, 3:55-61.

26. Usher SG, Radford AD, Villiers EJ, Blackwood L: RAS, FLT3, and C-KIT mutations in immunophenotyped canine leukemias. Exp Hematol 2009, 37:65-77.

27. Vandesompele J, De Preter K, Pattyn F, Poppe B, Van Roy N, De Paepe A, Speleman F: Accurate normalization of real-time quantitative RT-PCR data by geometric averaging of multiple internal control genes. Genome Biol 2002, 3:RESEARCH 0034.0031-0034.0011.

28. Bustin SA: Quantification of mRNA using real-time reverse transcription PCR (RT-PCR): trends and problems. J Mol Endocrinol 2002, 29:23-39.

29. Bereta J, Bereta M: Stimulation of glyceraldehyde-3-phosphate dehydrogenase mRNA levels by endogenous nitric oxide in cytokineactivated endothelium. Biochem Biophys Res Commun 1995, 217:363-369.

30. Zhu G, Chang Y, Zuo J, Dong X, Zhang M, Hu G, Fang F: Fudenine, a Cterminal truncated rat homologue of mouse prominin, is blood glucoseregulated and can up-regulate the expression of GAPDH. Biochem Biophys Res Commun 2001, 281:951-956

31. Zhang J, Snyder SH: Nitric oxide stimulates auto-ADP-ribosylation of glyceraldehyde-3-phosphate dehydrogenase. Proc Natl Acad Sci USA 1992, 89:9382-9385

32. Chang TJ, Juan CC, Yin PH, Chi CW, Tsay HJ: Up-regulation of beta-actin, cyclophilin and GAPDH in N1S1 rat hepatoma. Oncol Rep 1998, 5:469-471.

33. Bhatia P, Taylor WR, Greenberg AH, Wright JA: Comparison of glyceraldehyde-3-phosphate dehydrogenase and 28S-ribosomal RNA gene expression as RNA loading controls for northern blot analysis of cell lines of varying malignant potential. Anal Biochem 1994, 216:223-226.

34. Goidin D, Mamessier A, Staquet MJ, Schmitt D, Berthier-Vergnes O: Ribosomal 18S RNA prevails over glyceraldehyde-3-phosphate dehydrogenase and beta-actin genes as internal standard for quantitative comparison of mRNA levels in invasive and noninvasive human melanoma cell subpopulations. Anal Biochem 2001, 295:17-21.

35. Schmittgen TD, Zakrajsek BA: Effect of experimental treatment on housekeeping gene expression: validation by real-time, quantitative RTPCR. J Biochem Biophys Methods 2000, 46:69-81.

36. Huggett J, Dheda K, Bustin S, Zumla A: Real-time RT-PCR normalisation; strategies and considerations. Genes Immun 2005, 6:279-284.

37. Dheda K, Huggett JF, Bustin SA, Johnson MA, Rook G, Zumla A: Validation of housekeeping genes for normalizing RNA expression in real-time PCR. BioTechniques 2004, 37:112-114, 116, 118-119.

38. Nolan T, Hands RE, Bustin SA: Quantification of mRNA using real-time RTPCR. Nat Protoc 2006, 1:1559-1582.

39. Bustin SA, Benes V, Garson JA, Hellemans J, Huggett J, Kubista M, Mueller R, Nolan T, Pfaffl MW, Shipley GL, et al: The MIQE guidelines: minimum information for publication of quantitative real-time PCR experiments. Clin Chem 2009, 55:611-622.

40. Derveaux S, Vandesompele J, Hellemans J: How to do successful gene expression analysis using real-time PCR. Methods 50:227-230.

41. Brinkhof B, Spee B, Rothuizen J, Penning LC: Development and evaluation of canine reference genes for accurate quantification of gene expression. Anal Biochem 2006, 356:36-43.

42. Schlotter YM, Veenhof EZ, Brinkhof B, Rutten VP, Spee B, Willemse T, Penning LC: A GeNorm algorithm-based selection of reference genes for quantitative real-time PCR in skin biopsies of healthy dogs and dogs with atopic dermatitis. Vet Immunol Immunopathol 2009, 129:115-118.

43. Andersen $C L$, Jensen $J L$, Orntoft TF: Normalization of real-time quantitative reverse transcription-PCR data: a model-based variance estimation approach to identify genes suited for normalization, applied to bladder and colon cancer data sets. Cancer Res 2004, 64:5245-5250.

44. Peters IR, Peeters D, Helps CR, Day MJ: Development and application of multiple internal reference (housekeeper) gene assays for accurate normalisation of canine gene expression studies. Vet Immunol Immunopathol 2007, 117:55-66.

45. Raaijmakers MH, van Emst L, de Witte T, Mensink E, Raymakers RA: Quantitative assessment of gene expression in highly purified hematopoietic cells using real-time reverse transcriptase polymerase chain reaction. Exp Hematol 2002, 30:481-487.

46. Thorrez L, Van Deun K, Tranchevent LC, Van Lommel L, Engelen K, Marchal $K$, Moreau Y, Van Mechelen I, Schuit F: Using ribosomal protein genes as reference: a tale of caution. PLoS One 2008, 3:e1854.
47. Hartel C, Bein G, Muller-Steinhardt M, Kluter H: Ex vivo induction of cytokine mRNA expression in human blood samples. J Immunol Methods 2001, 249:63-71.

48. Etschmann B, Wilcken B, Stoevesand K, von der Schulenburg A, SternerKock A: Selection of reference genes for quantitative real-time PCR analysis in canine mammary tumors using the GeNorm algorithm. Vet Pathol 2006, 43:934-942.

49. Stamova BS, Apperson M, Walker WL, Tian Y, Xu H, Adamczy P, Zhan X, Liu DZ, Ander BP, Liao IH, et al: Identification and validation of suitable endogenous reference genes for gene expression studies in human peripheral blood. BMC Med Genomics 2009, 2:49.

50. DeRisi JL, lyer VR, Brown PO: Exploring the metabolic and genetic control of gene expression on a genomic scale. Science 1997, 278:680-686.

51. Tanaka S, Furukawa T, Plotkin SA: Human cytomegalovirus stimulates host cell RNA synthesis. J Virol 1975, 15:297-304.

doi:10.1186/1756-0500-4-36

Cite this article as: Piek et al:: Leukocyte count affects expression of reference genes in canine whole blood samples. BMC Research Notes 2011 4:36.

\section{Submit your next manuscript to BioMed Central and take full advantage of:}

- Convenient online submission

- Thorough peer review

- No space constraints or color figure charges

- Immediate publication on acceptance

- Inclusion in PubMed, CAS, Scopus and Google Scholar

- Research which is freely available for redistribution

Submit your manuscript at www.biomedcentral.com/submit
Ciomed Central 